\title{
Introduction
}

Bogdan Murgescu, Viorel Proteasa*, Jan Sadlak

\section{Long term perspectives on higher education: student movements, human capital and expert culture}

https://doi.org/10.2478/irsr-2018-0002

\begin{abstract}
This special issue aims at providing an empirical, analytically grounded perspective on foremost European higher education, while pointing at historical references, path-dependencies, critical junctures, and "original" institutional settings determined by the interaction of new forms with historical legacies. The contributions collected depict different facets of long term transformations of higher educations and, in some cases, their interplay with critical moments characterized by ample and abrupt transformations. Geographically, this issue includes study-cases localized in Central and Eastern Europe (the Czech Republic, Hungary, Poland and Romania), Western Europe (Italy and Germany) and Africa (Ghana). One of the express aims of the special issue is to bring together analyses focusing on national and/or local case studies, which have the potential to constitute the basis for comparative analysis.
\end{abstract}

Keywords: higher education, long term transformations, students' organizations, protests, governance, subjective experiences

\section{Introduction}

The second half of the $20^{\text {th }}$ century was a period of significant expansion of tertiary education throughout the world. The number of students grew exponentially, the institutional landscape of higher education diversified, the share of university graduates on the labor market

\footnotetext{
*Corresponding author: Viorel Proteasa, West University of Timișoara, Romania, E-mail: viorel.proteasa@e-uvt.ro

Bogdan Murgescu, University of Bucharest, Romania

Jan Sadlak, IREG Observatory on Academic Ranking and Excellence
}

became more significant than ever before, and their impact on the overall economic performance of various societies also increased. In countries of widely-understood Europe Region, the process has gained a new dimension in the context of the collapse of ideologically-divided Europe, complemented by sectoral specific pan-European cooperation, such as the Bologna Process.

This special issue aims at providing empirical, analytically grounded perspectives on mainly European higher education, while pointing at historical references, path-dependencies, critical junctures, and "original" institutional settings determined by the interaction of new forms with historical legacies. The contributions collected in this special issue depict different facets of long term transformations of higher educations. The analytical perspectives employed are diverse, inviting the reader to engage with one of the grand issues of the social sciences, that of the relation between structure and agency (Archer, 2010; Giddens, 1984). Geographically, this issue includes study-cases localized in Central and Eastern Europe (the Czech Republic, Hungary, Poland and Romania), Western Europe (Italy and Germany) and Africa (Ghana).

One of the express aims of the special issue is to bring together analyses focusing on national and/or local case studies, which have the potential to constitute the basis for comparative research. As such, we will indicate in this short introduction the links between the articles which can serve as possible vantage points for comparative analyses. In doing so, we will tackle some of what we consider to be the key research questions for such comparative ventures.

\section{Students' organizations in Central and Eastern European: similar departures, divergent paths}

Students' organizations are the main characters of a first set of five articles, which contribute to the thread 
of research initiated by Phillip Altbach (Altbach, 1989, 2006; Lipset \& Altbach, 1966) and advanced by Manja Klemenčič (Klemenčič, 2012a, 2015). These study-cases are circumscribed to three countries, the Czech Republic, Poland and Romania, and illustrate what we consider to be different avenues of transformation from the campus arrangements of the communist regimes to more recent changes, under the influence of the Bologna Process.

On one hand, thesearticles tell a story of organizational resilience: actors which capitalize on the structure of political opportunity in a certain historical context lose their dominance over the organizational field ${ }^{1}$, under the impetus of social and political transformations. Faced with a changing context, they adjust (or not) their repertoire of action. In this perspective of almost 40 years, Smużewska (2018) analyses the Polish campus as a contested terrain, with students' organizational actors engaging in cooperative relations with actors which are confined to the higher education sector - especially in the recent years, or in rather contentious relations with actors which are rather external to the campus - especially in the 1980s and early 1990s. In our opinion, this contribution adds a welcome agency perspective to previous accounts on Polish student representation in the international literature (Antonowicz, Pinheiro, \& Smużewska, 2014), but also to social movement research on Poland (Ekiert \& Kubik, 1998a, 1998b, 2001).

The three study-cases on Romanian students' organizations paint the image of a divergent path - a course of action with different outcomes in a rather similar historical context. (And one potentially crucial difference: whereas the communist-era Polish students' organizations survived the fall of communism, in Romania the communists' student associations collapsed completely at the end of 1989.) In a chronological ordering of the three contributions, the scene-setting role is taken by the article of Matei Gheboianu and Bogdan Murgescu. They document in detail two moments which we consider to be illustrative for the transformation of the Romanian universities in 1990: the decision of the students to blacklist the un-desirable professors and the first electoral competition for the seats in universities. We share the authors' opinion that the 'black-lists' were complex social phenomena, involving personal confrontations and having a public, even spectacular, component. As they have two rationales, one academic and one political, they do not easily fit within current approaches to similar events in other sectors of society, typically circumscribed to lustration and transitional justice (Stan, 2012; Stan \&

1 See the conceptualization of McAdam \& Scott (2005).
Nedelsky, 2015). Without engaging in a long discussion on the nature of these 'student assessments', we limit ourselves to mentioning that up to this moment we did not find in the available secondary literature information about other events with similar features after 1990 - in Romania or elsewhere. The relation of power between the students and the professorate in the immediate aftermath of the Romanian revolution - which is hardly imaginable under current arrangements, remains a topic which deserves future investigation in a comparative outlook.

While documenting the first electoral competition for leadership seats in universities, Gheboianu \& Murgescu (2018) outline one of the mechanisms through which the newly established student organizations secured a dominant position in the university: political influence in elections, under a very particular and advantageous institutional arrangement - student representatives' veto over all decisions. Building on such facts and other documentary sources Proteasa et al. (2018) tell the story of the emergence of a certain organizational category treated as an archetype. They analyze the evolution of the national 'higher-order associations' or federations - an analytical equivalent of the 'national unions of students' of Klemenčič (2012a). The analysis of Proteasa et al. (2018) accounts for transformations under shifting political opportunities in a context of structural (quasi-) continuity. The analysis of Gheboianu \& Murgescu (2018) dwells on the disruptiveness brought by the transition from communism in Romania.

The operations of the students' organizations documented by Pușa Năstase adds another welcome perspective to the evolutionary story told by the three articles when read together. She provides useful insights on some of the mechanisms at work in processes of professionalization (Brooks, Byford, \& Sela, 2015; Klemenčič, 2012b; Schmitter \& Streeck, 1999). Her conclusion makes a puzzling point: despite the lack of resources and high 'personnel' turnover, Romanian students' organizations have travelled more towards professionalization than the universities in which they operate.

Mirroring the contributions on Poland and Romania, Jiři Nantl offers a comprehensive overview of the evolution of student representation in the Czech Republic, thus complementing previous accounts on the topic, in this national setting (Pabian, Hündlová, \& Provázková, 2011). He discusses the emergence of the Czech 'national union of students' - a term coined in the scientific literature by Manja Klemenčič, in the context of the early restauration of universities' inter-war priviledges following the Velvet Revolution. Though the result of a top-down structuration 
in the first half of the nineties, the story told by Nantl (2018) is far from being a closed chapter. It refers to contestation and conflict on behalf of organized groups of constituents, but also protests against governmental auhtorities and new organizational actors challenging the position of SK RVŠ the federation established in the nineties.

Overall, these case-studies on students' collective action in Central and Eastern Europe countries, their organizations and their relations with the authority, be it centralized or deployed at university management levels, bring new insights related to the long-term transformation in the post-communist periods, circumscribed to the dynamics of the relevant organizational fields, especially professionalization, competition and representational monopoly, or Europeanization. They also fill in what we consider to be a gap in the scientific literature - students' organizations and their role in protests is a topic which did not receive the attention it deserves, with the notable exceptions already referenced in the previous paragraphs, and other authors dealing with the topic in different national contexts (Chirikov \& Gruzdev, 2014; Crossley \& Ibrahim, 2012; Foroni, 2011; Jungblut \& Weber, 2012, 2015; Klemenčič, Bergan, \& Primožič, 2015; Luescher-Mamashela \& Mugume, 2014; Parejo \& Lorente, 2012; Popović, 2015; Szabo, 1998).

\section{System transformations, organizational adjustment and contentious politics}

A second set of articles are constructed starting from a wider analytical unit: the policy system. In his account on Italy, Gianni Piazza discusses the successive waves of mobilization against a "neoliberal" agenda: "the combination of centralization of decision-making powers at the top of single institutions with the growing financial autonomy of the same; the introduction of a competitive and market logic (according to the school of the New Public Management), external financiers and private stakeholders, the performance reward mechanisms, both individually and as a system, for evaluation and accreditation of courses, departments and universities" Piazza (2018). In doing so, the author identifies with an insider's knowledge of detail the actors involved, the claims they articulated and the repertoires of action they employed. The scope of research is impressive, covering the period since 1989-90 the student movement of the so-called 'Panther', until 2017.

Though that is not the main focus of his article Piazza (2018) offers relevant insights for research on student protests and organizations - possible venues of cooperation. $\mathrm{He}$ presents the contentious character of students' organization in Italy, with the "the main traditional student union", previously described in the international literature (Foroni, 2011) being marginalized by new actors - students groups in the protests within the 2008 Anomalous Wave.

The second article covers a similar period of system transformation in Hungarian higher education, with a different focus and a different theoretical background. Borrowing insights from organizational studies contingency theory, specifically - Gergely Kováts explores organizational responses to changes coming from policies and from the market, in search of patterns towards efficiency. An attentive reader able to mitigate the different theoretical view-points would identify similar stimuli - exogenous factors - in the two articles. While Kováts (2018) analyses organizational responses within the range of political and administrative behaviours confined to the political system, Piazza (2018) puts under scrutiny political behaviours which fall outside the formal system, as predicted in situations in which actors conceive of the (political) opportunities as being closed (Giugni, 2011; Koopmans, 1999; Kriesi, 2004; Meyer \& Minkoff, 2004).

\section{Subjectivity and the transformation of the higher education landscape}

A third set of contributions explore subjectivity in the realm of higher education. Davide Filippi explores subjectivity in connection with Italian 'temp' researchers' responses to the changing nature of the academic profession. As such, the article pairs well with the contribution of Piazza (2018). While the former discusses aggregate responses to the reforms which take the form of protests, Filippi (2018) explores researchers' changing perceptions of the self, associated with the transition from a system where tenured careers were the (expected) standard to instable, "precarious" forms of employment. In doing so, he touches on the organization and repertoire of action of the "Nontenured Researchers' Coordination”, which is presented as the main collective actor opposing the transformation of the researchers within Italian universities starting 2015. The contentious character of the campus is once again substantiated through the conflict between the established branch of "a traditional type of [labour] union" (Filippi, 2018) and the newly established actor, with a different organization and repertoire of action - resembling more the international social movement type and less the "logic of influence” (Schmitter \& Streeck, 1999). Both Filippi (2018) and Piazza (2018) seem to operate with a presumption that, 
in neo-corporatist systemic arrangements (Schmitter, 1974), opportunity structures are perceived as open due to access to administrative resources. This presumption can be also justified as a theoretical implication and is widely shared in the literature (Klemenčič, 2012a; McLaughlin, Scott, Deschenes, Hopkins, \& Newman, 2009).

The contribution of Knut Petzold and Hannah Bucher addresses subjective responses to another facet of the internationalisation of higher education - mobility, a facet of internationalisation which is common to higher education policy documents and related scientific literature. While Filippi (2018) rather addresses individuals' resistance to the consequences of the globalising "neoliberal" agenda explicated by Piazza (2018), Petzold \& Bucher (2018) explore how ideological constructs associated with internationalisation enter the normative symbolic space of the individuals. It is interesting to note the conflicting perspectives on the Bologna Process - the transnational cooperation in Europe. While Petzold \& Bucher (2018) identify positive consequences associated with internationalisation via Europeanization through the Bologna Process, both contributions on Italy attest to a negative framing of the same political process, on behalf of those involved in the protests against the successive transformations of Italian higher education. While the ideological consistency of these negative claims is questionable on a close inspection of the principles of the Bologna Process (Zgaga, 2012), we can speculate on the possibility that the different perceptions are determined by the policy focus or by the actors which mediate between transnational political processes and the people in the lecture halls, and the manner in which they do this.

The contribution by Esmeranda Manful and Michael Atakora explores students' subjectivity in accessing social protection within a programme implemented by Kwame Nkrumah University of Science and Technology which aims to ensure equality of opportunity. Though geographically the article may seem distant from the others - which deal with higher education in Europe -, we find it illustrative for the behaviour of the beneficiaries of policies which are framed under the Bologna Process as the "social dimension", and are regarded as a 'moving target' with a rather unclear shape (Kooij, 2015).

\section{Concluding remarks}

The different analytical units used by the contributors to this special issue present the advantage of a diversity not only of empirical findings, but also of mechanisms which account for the social processes associated with the long- term evolutions of higher education. We insisted in this introduction to the special issue on the complementarities among the contributions assembled together and on the research questions which arise in this juxtaposing perspective. We also insisted on complementarities throughout the review process, and thank the authors for their willingness to accept such a perspective on the special issue.

This approach comes with the cost of the theoretical and methodological diversity of the contributions, which requires the reader not only to change focus from one analytical unit to another, but also to switch among different theoretical traditions. We tried to make the special issue topic-driven, hence accessible for a wide audience of scholars and practitioners. Still, an experienced reader will easily identify not only theoretical perspectives which are not easily bridged, but also the varied epistemological allegiances of the authors.

\section{Funding}

The contribution of Viorel Proteasa was supported through the research project 'From Corporatism to Diversity: A Neoinstitutionalist Study of Representative Student Organizations in Postcommunist Romania' (code PN-II-RU-TE-2014-4-2296, contract no. 379/2015), funded under the Human Resources - Young Teams programme of Romania's National Plan for Research, Development and Innovation (PN2).

The work of Bogdan Murgescu was supported by a grant of the Romanian National Authority for Scientific Research, CNCS - UEFISCDI: "Economic Planning, Higher Education, and the Accumulation of Human Capital in Romania during Communism (1948-1989)" (code PN-II-IDPCE-2011-3-047).

\section{References}

Altbach, P. G. (1989). Student political activism : an international reference handbook. New York: Greenwood Press.

Altbach, P. G. (2006). Student Politics: Activism and Culture. In P. G. Altbach \& J. J. F. Forest (Eds.), International Handbook of Higher Education (pp. 329-45). Springer International Publishing. https://doi.org/10.1007/s11618-008-0047-x

Antonowicz, D., Pinheiro, R., \& Smużewska, M. (2014). The changing role of students' representation in Poland: an historical appraisal. Studies in Higher Education, 39(3), 470-484. https://doi.org/10.1080/03075079.2014.896182

Archer, M. S. (2010). Morphogenesis versus structuration: On combining structure and action. British Journal of Sociology, 61(SUPPL. 1), 225-252. https://doi.org/10.1111/j.14684446.2009.01245.x 
Brooks, R., Byford, K., \& Sela, K. (2015). The changing role of students' unions within contemporary higher education. Journal of Education Policy, 30(2), 165-181. https://doi.org/10. 1080/02680939.2014.924562

Chirikov, I., \& Gruzdev, I. (2014). Back in the USSR: path dependence effects in student representation in Russia. Studies in Higher Education, 39(3), 455-469. https://doi.org/10.1080/03075079 .2014 .896181

Crossley, N., \& Ibrahim, J. (2012). Critical Mass, Social Networks and Collective Action: Exploring Student Political Worlds. Sociology, 46(4), 596-612. https://doi.org/10.1177/0038038511425560

Ekiert, G., \& Kubik, J. (1998a). Collective protest in post-communist Poland, 1989-1993: a research report. Communist and Post-Communist Studies, 31(2), 91-117. https://doi. org/10.1016/S0967-067X(98)00002-6

Ekiert, G., \& Kubik, J. (1998b). Contentious Politics in New Democracies: East Germany, Hungary, Poland and Slovakia, 1989-93. World Politics, 50(4), 547-581. https://doi. org/10.1177/0094306110367909c

Ekiert, G., \& Kubik, J. (2001). Rebellious Civil Society: Popular Protest and Democratic Consolidation in Poland, 1989-1993. University of Michigan Press.

Filippi, D. (2018). Research scholars: temp workers or lifetime students? The struggle and organization of subjectivities that are "in between." International Review of Social Research, 8(1).

Foroni, M. (2011). Student Representation in Italy. Tertiary Education and Management, 17(3), 205-218. https://doi.org/10.1080/135 83883.2011.588718

Gheboianu, M., \& Murgescu, B. (2018). Student Assessment of Professors in Revolutionary Context. Case-Study: The History Faculty of the University of Bucharest (1989-1990). International Review of Social Research, 8(1).

Giddens, A. (1984). The constitution of society: outline of the theory of structuration. Berkeley: University of California Press.

Giugni, M. (2011). Political opportunity: still a useful concept? Contention and Trust in Cities and States, 305-322. https://doi. org/10.1007/978-94-007-0756-6

Jungblut, J., \& Weber, R. (2012). National student governance in Germany: the case of fzs. European Journal of Higher Education, O(0), 1-16. https://doi.org/10.1080/21568235.201 2.683701

Jungblut, J., \& Weber, R. (2015). We Are One, But Not the Same: Explaining the Emergence of Hybrid National Student Unions. In M. Klemenčič, S. Bergan, \& R. Primožič (Eds.), Student Engagement in Europe: Society, Higher Education and Student Governance (pp. 269-282). Council of Europe Publishing.

Klemenčič, M. (2012a). Student representation in Western Europe: introduction to the special issue. European Journal of Higher Education, 2(1), 2-19. https://doi.org/10.1080/21568235.201 2.695058

Klemenčič, M. (2012b). The Changing Conceptions of Student Participation in HE Governance in the EHEA. In A. Curaj, P. Scott, L. Vlăsceanu, \& L. Wilson (Eds.), European Higher Education at the Crossroads: Between the Bologna Process and National Reform (pp. 631-653). Dordrecht: Springer Netherlands. https://doi.org/10.1007/978-94-007-3937-6

Klemenčič, M. (2015). What is student agency? An ontological exploration in the context of research on student engagement. In M. Klemenčič, S. Bergan, \& R. Primožič (Eds.), Student engagement in Europe: society, higher education and student governance (pp. 11-29). Strasbourg: Council of Europe.

Klemenčič, M., Bergan, S., \& Primožič, R. (Eds.). (2015). Student Engagement in Europe: society, higher education and student governance. Strasbourg: Council of Europe Publishing.

Kooij, Y. (2015). The Social Dimension of the Bologna Process. In European Higher Education Policy and the Social Dimension: A Comparative Study of the Bologna Process (pp. 57-100). London: Palgrave Macmillan UK. https://doi. org/10.1057/9781137473141_4

Koopmans, R. (1999). Political. Opportunity. Structure. Some Splitting to Balance the Lumping. Sociological Forum, 14(1), 93-105. https://doi.org/10.2307/685018

Kováts, G. (2018). The change of organizational structure of higher education institutions in Hungary: a contingency theory analysis. International Review of Social Research, 8(1).

Kriesi, H. (2004). Political Context and Opportunity. In D. A. Snow, S. A. Soule, \& H. Kriesi (Eds.), The Blackwell Companion to Social Movements (pp. 67-90). Malden: Blackwell.

Lipset, S. M., \& Altbach, P. G. (1966). Student Politics and Higher Education in the United States. Comparative Education Review, 10(2), 320-349. https://doi.org/http://www.jstor.org/ stable/1186225

Luescher-Mamashela, T. M., \& Mugume, T. (2014). Student representation and multiparty politics in African higher education. Studies in Higher Education, 39(3), 500-515. https://doi.org/10.1080/03075079.2014.896183

Manful, E., \& Atakora, M. (2018). Work and study: exploring the social actions of undergraduates on a social protection scheme in Ghana. International Review of Social Research, 8(1).

McAdam, D., \& Scott, W. R. (2005). Organizations and Movements. In G. F. Davis, D. McAdam, W. R. Scott, \& M. N. Zald (Eds.), Social Movements and Organization Theory (pp. 4-40). Cambridge University Press.

McLaughlin, M., Scott, W. R., Deschenes, S., Hopkins, K., \& Newman, A. (2009). Between movement and establishment: Organizations Advocating for youth. Stanford: Stanford University Press.

Meyer, D. S., \& Minkoff, D. C. (2004). Conceptualizing Political Opportunity. Social Forces, 82(4), 1457-1492. https://doi. org/10.1353/sof.2004.0082

Nantl, J. (2018). Academic Citizens: The story of Czech national student organization after the Velvet Revolution. International Review of Social Research, 8(1).

Năstase, P. (2018). Hidden in plain sight: student fund-raising in Romanian universities. International Review of Education., 8(1).

Pabian, P., Hündlová, L., \& Provázková, K. (2011). The Czech Republic Between Studentocracy, Academic Oligarchy and Managerialism: Are students powerful or powerless? Tertiary Education and Management, 17(3), 191-203. https://doi.org/10 $.1080 / 13583883.2011 .588721$

Parejo, J. L., \& Lorente, J. (2012). From student associations to CEUNE: the development of student representation in Spain. European Journal of Higher Education, 2(1), 78-94. https://doi. org/10.1080/21568235.2012.691245

Petzold, K., \& Bucher, H. (2018). The Academic Mobility Regime: Analysing Perceptions of Students and Academic Staff. International Review of Social Research, 8(1). 
Piazza, G. (2018). Not only students, but also not enough: the waves of protest in the higher education in Italy. International Review of Social Research, 8(1).

Popović, M. (2015). Parliaments or streets ? In M. Klemenčič, S. Bergan, \& R. Primožič (Eds.), Student Engagement in Europe: society, higher education and student governance (pp. 99-112). Strasbourg: Council of Europe Publishing.

Proteasa, V., Andreescu, L., Botgros, V., \& Dodiță, A. (2018). Mapping students' organizations in post-communist Romania: a structuration perspective. International Review of Social Research, 8(1).

Schmitter, P. C. (1974). Still the Century of Corporatism? The Review of Politics, 36(1), 85-131. https://doi.org/10.1017/ S0034670500022178

Schmitter, P. C., \& Streeck, W. (1999). The Organization of Business Interests. Studying the Associative Action of Business in Advanced Industrial Societies. Köln: Max Planck Institut für Gesellschaftsforschung.
Smużewska, M. (2018). The Polish student movement after the fall of the Iron Curtain: An organisational perspective. International Review of Social Research, 8(1).

Stan, L. (2012). Transitional Justice in Post-Communist Romania. New York: Cambridge University Press. https://doi. org/10.1017/CB09781139104227

Stan, L., \& Nedelsky, N. (Eds.). (2015). Post-Communist Transitional Justice. New York: Cambridge University Press. https://doi. org/10.1017/CB09781107588516

Szabo, M. (1998). New Social Movements in Hungary. Soundings, (9), 1-14.

Zgaga, P. (2012). Reconsidering the EHEA Principles: Is There a "Bologna Philosophy"? In A. Curaj, P. Scott, L. Vlasceanu, \& L. Wilson (Eds.), European Higher Education at the Crossroads (pp. 17-38). Dordrecht: Springer Netherlands. https://doi.org/ https://doi.org/10.1007/978-94-007-3937-6_2 